\title{
Лидија Танушевска
}

lidkapol@yahoo.com

\section{Збогување со магијата во преводот на Виткаци}

\begin{abstract}
Tanuševska Lidija, Zboguvanje so magijata vo prevodot na Vitkaci (Farewell to the Magic in the Translation of Witkacy). „Poznańskie Studia Slawistyczne” 4. Poznan 2013. Adam Mickiewicz University Press, pp. 309-318. ISBN 978-83-232-2525-6. ISSN 2084-3011.

This article reveals theoretic aspects on literary translation through the analyses of the translation of the novel Farewell to the autumn by Polish writer Stanislaw Ignacy Witkiewicz. It concerns the competences and skills a translator of literature should have. Among other topics which have been analyzed, there is the creativeness, knowledge of cultural differences, writing skills in the goal-language. The analyses prove that it's not that simple to translate literature and that it's a special type of translation in the typology of translations. The article presents a list of most commonly made mistakes by translators who are not yet fit to translate literature of this kind. Translation of highly rated literature is a kind of magic, because of the effect they produce on the reader, and the translator should be skilled in making the magic of the words.
\end{abstract}

Keywords: literary translation, competencies, mistakes, creativeness, stylization, standard, language

Предмет на овој труд е анализа на преводот низ примери од романот Збогувағе со есента од Стањислав Игнаци Виткјевич ${ }^{1}$ на македонски јазик, со цел попрецизно да се одредат компетенциите на еден книжевен преведувач и да се укаже на комплексноста на книжевниот превод како процес и производ. Преводот на романот Збогување со есента од Виткаци на македонски јазик претставува револуционерен потфат на преведувачот, со оглед на тоа што Виткаци не бил преведуван во оваа средина, освен неколкуте фрагменти од истиот роман и неколку есеи од и за неговото творештво во почетокот на деведесеттите години. Сепак, неговото влијание на развојот на помладата

\footnotetext{
${ }^{1}$ С.И. Виткјевич, Збогување со есента, прев. А. Тодевска, Скопје 2011.
} 
македонска литература не изостанал, бидејќи мал но вреден интелектуален круг го познавал неговото творештво, главно од преводи на други јазици или од оригиналот, и бил свесен за неговиот придонес во компаративната книжевност.

Со оглед на тоа што македонскиот роман има задоцнет почеток, односното прозното творештво започнува допрва по Втората светска војна, овој превод внесува значаен удел во комплетната слика за светското литературно творештво во меѓувоениот период, кое е одраз на новите книжевни изрази, форми на пишување, стилови и идеи. Отфрлањето на реалноста и чувството на хаотичен сон, во кој јунакот има одлики на лудак во светот кој и така не е „нормален”, не е препознатливо само за Виткаци, туку и за некои од современите македонски писатели во шеесеттите и седумдесеттите години. Па, затоа, овој превод е од огромно значење за македонската литературна сцена како извор на споредбени истражувања и како пример за специфичен стил на пишување, кој е ретко повторлив во слична форма. Во тој поглед, преводот на Збогување со есента, како една целина во која е пренесена идејата на декадентноста, визионерството и распадот на идентитетот, во кој може да се насети оригиналноста на гротескниот јазик во кој се меша стилот на филозофски трактат со вулгарноста на уличниот говор, како дело со признаени високи уметнички вредности, навистина претставува настан во македонската книжевна преведувачка дејност.

Што се однесува до преводот, пак, тој, сфатен многу широко во границите на семантичкото поле, е резултат на еден интердисциплинарен дијалог. Тоа значи дека неговиот процес вклучува многу вонлингвистички аспекти и различни научни дисциплини, како, на пример, комуникологијата, при што „целта на преводот е да се пренесе содржината на оригиналот на туѓиот читател”2; културологијата, бидејќи во процесот на преведувањето преведувачот ги прилагодува своите стратегии спрема општествениот и културниот контекст на целниот текст; науката за литература, со оглед на тоа што предмет на интерес е текстот на преводот, а секој превод содржи извесен степен на манипулација со текстот на оригиналот и креативност, затоа што талентот за пишување, па и преведување, се огледува во умешноста

\footnotetext{
2 J. Levi, Umjetnost prevođenja, prev. B.L. Dabić, Sarajevo 1982, стр. 395.
} 
на обичните работи да се гледа на необичен начин, што, пак, навлегува во сферата на когнитивизмот, односно, когнитивистичкиот пристап на концептуализација на светот. Тука е изложен само дел од теориските аспекти кон определувањето на преводот како предмет на истражување на една наука.

Преводот претставува еден нов текст, различен од оригиналот, и со самото тоа дава неброени можности за повторна анализа и споредување со оригиналниот текст. „Одлика на секој превод е многукратноста и повторливоста, односно е еден од многуте можни искази”, според Едвард Балцежан ${ }^{3}$, или, како што вели Волтер Бенјамин: тој му овозможува понатамошна егзистенција на делото и на јазикот преку ослободување на делото од власта на авторот и обновување на јазикот преку другиот јазик ${ }^{4}$. Преводот го сфаќаме како напишан текст чија структура зависи од тоа како ќе го оформи неговиот преведувач, односно автор, и како таков зависи од повеќе фактори: јазичната и вонјазичната компетенција на авторот, начинот на неговата комуникација со целната група на која и е наменет тој текст, средствата со кои се постигнуваат различни функционални стилови, решенијата што се употребуваат за преведување на „непреводливото” и сл. Се разбира, главнината на оваа постструктуралистичка теорија на преводот се однесува на книжевниот превод кој го сфаќаме како одделен вид превод во типологијата на преводот.

Една од најистакнатите разлики меѓу книжевниот и некнижевниот превод е значењето што го има личноста на преведувачот во однос на авторот на преведуваното дело. (...) Имено, книжевен текст не може да функционира без духот на неговиот автор, а ваквата димензија на оригиналот би требало да има свој одраз и во преводот. (...) Во книжевниот превод често се случува преведувачот да ги надмине границите на преводот, со што навлегува во сферата на уметничката креација [прев. Л.Т.] $]^{5}$.

Во ова дело авторот оцртува една катастрофистичко-еротска визија на пропаѓањето на декадентниот свет, а таа визија се состои од

\footnotetext{
${ }^{3}$ E. Balcerzan, Literatura z literatury. Strategia ttumaczy, Katowice 1998, стр. 225.

${ }^{4}$ Цит. од: Д. Михајловски, Под Вавилон - задагата на преведувагот, Скопје 2002, стр. 124.

${ }^{5}$ J. Pieńkos, Podstawy przekładoznawstwa. Od teorii do praktyki, Kraków 2003, стр. 78 .
} 
барањето на тајната на постоењето, талкањето меѓу уметноста и животот, еротиката, наркотиците и филозофирањето. Авторот има создадено сопствен стил, неговата реченица има особена структура, игрите со зборови имаат клучно значење за текстот, а во него се појавува и изобилство на неологизми, односно индивидуализми, измислени од него самиот. Па, затоа и преведувачот на една ваква уметничка творба е поставен пред многу тешка и одговорна задача, односно треба да ја долови таа метафизика во овој несекојдневен роман. Во повеќето контексти преведувачот се справува со гротескната доминанта што го обележува стилот на Виткаци, интерпретацијата во однос на лексемите својствени за него, исто така, е на завидно ниво, но комплетната слика на светот претставен во романот Збогување со есента е испрекршена и заматена поради попатните грешки, недоследности и недостатоци кои го попречуваат течното читање што би требало да биде одлика на добриот превод.

Имено, во книжевниот превод е важна креативноста, инспирацијата и добриот вкус, но тоа, сепак, не значи дека тој е привилегиран и не мора да ги следи другите правила на играта, односно да не ги почитува правилата што се однесуваат на сите видови превод. Една од основните компетенции за секој вид превод е доброто познавање на јазикот од кој се преведува и на кој се преведува, и тоа на сите нивоа: фонетика, морфологија, синтакса, зборообразување, лексикологија, стилистика, семантика, историја и дијалектологија на јазикот. Овде, особено треба да се подвлече познавањето на јазикот на кој се преведува, а најчесто тоа е мајчиниот јазик. Преведувачот треба да е свесен за она што не е стандард во целниот јазик. За илустрација ќе ги земеме следниве примери од споменатиот превод:

1а. Ве охрабрив да ме бакнувате, но не и да ме запросите (стр. 24$)^{6}$.

16. ośmieliłam pana do pocałunków, ale nie do oświadczyn (стр. 25).

2а. Чезнеејќи помисли на оној „мрак”... (стр. 20).

26. Z utęsknieniem pomyślał o tamtym „mroku”... (стр. 22).

3а. Атанази со десната рака ѝ го покри лицето, истовремено навалувајќи ја со левата наназад, фаќајќи ѝ го левото раме одзади (стр. 25).

${ }^{6}$ Во оваа статија, при цитирањето на изворот, бројот на страниците во заградата се однесува на следниве изданија: (стр. ) - С.И. Виткјевич, Збогување со есента; (стр. ). S.I. Witkiewicz, Pożegnanie jesieni, Kraków 2010. 
36. Atanazy zakrył jej twarz prawą ręką, przeginając ją jednocześnie lewą w tył, chwyciwszy jej lewe ramię od tyłu (стр. 26).

Сите потцртани лексеми во примерите не се прифатливи во македонскиот стандарден јазик и се сметаат за србизми. Такви одредници не можат да се најдат во Правописот на македонскиот литературен јазик ${ }^{7}$, ниту пак во некој од Толковните речниции на македонскиот јазик, во изданија на институциите кои се одговорни за грижата за македонскиот јазик во Република Македонија. Затоа, пак, можат да се најдат во македонските толковни речници на интернет, кои, сепак, се невалидни извори, а целта им е да се овозможи што полесна комуникација. Совесниот и сериозен преведувач, особено на ваква литература, која има висока уметничка вредност, би требало да знае каде треба да ја проверува валидноста на одредени лексеми. А особено, во овој случај, кога постојат соодветни и доста фреквентни еквиваленти во литературниот јазик: 1) да ми ја побарате раката или да ме побарате за жена; 2) со носталгија или копнежливо (бидејќи во оригиналот стои: z utęsknieniem); 3) рамо. Овде се набројани само дел од ваквите грешки низ целиот превод. Во овој случај, магијата на еден возвишен говор меѓу благородници, интелектуалци и уметници од типот на ликовите во Збогување со есента се губи и наместо тоа нивниот говор наликува на уличниот жаргон на младите Македонци во нашево современие, а таква стилизација овде е непотребна.

Следниве примери ја покажуваат некомпетенцијата на преведувачот во однос на синтаксата на македонскиот стандарден јазик:

4a. Завршениот пред неколку минути телефонски разговор како да помина крај него во форма на две метални чинии... (стр. 15).

46. Przebrzmiała przed chwila telefoniczna rozmowa przeleciała jakby obok niego w postaci uderzających o siebie metalowych blaszek... (стр. 15-16).

5а. ...тоа повеќе беше одбивност кон кинење на тенкиот слој на благородни материјали, под кој се сместуваше лесната до заглавување тиња... (стр. 18).

56. ... był to raczej wstręt do złamania cienkiej warstewki szlachetniejszych materiałów, pod którą rozgaszczało się łatwe do przyjemnego zabrnięcia bagno... (стр. 19).

${ }^{7}$ Б. Видоески, Т. Димитровски, К. Конески, Р. Угринова-Скаловска, Правопис на македонскиот литературен јазик, Скопје 1999. 
Ваков тип конструкции често се среќаваат во овој превод, а за жал и во новинарскиот стил, а го прават текстот неразбирлив и непотребно компликуван. Тие се директна интерференција од други јазици, додека во македонскиот стандард е недопустливо развиената придавска определба да се става пред именката. Имено, „предикативниот атрибут се јавува како резултат само на релацијата на вистинска предикација, т.е. само во нечленуван вид (...) интегрираниот придавски предикативен атрибут претставува развиена определба чие место е задолжително зад центарот на именската група"8. Што значи, овие реченици би требало да изгледаат вака: „Телефонскиот разговор, завршен пред неколку минути, како да помина крај него во форма на две метални чинии и тоа повеќе беше одбивност кон кинење на тенкиот слој на благородни материјали, под кој се сместуваше тињата, лесна до заглавување".

Една од компетенциите на добриот преведувач е и вештината за јасно и прецизно формулирање на мислите и логично размислување, што ќе го направи текстот лесен за читање, а во исто време нема да ја загуби магијата на стилот на авторот, кој е далеку од едноставен. Прецизноста и издржливоста се чинат како небитни компетенции во однос на преведувањето, но следниве примери покажуваат дека тоа не е така:

6а. Пред половина час Атанази реши да појде кај Хели Бертс (стр. 11).

6б. Pół godziny temu Atanazy definitywnie postanowił pójść do Heli Bertz (стр. 11).

Во овој пример се работи за еден од главните ликови, кој се вика Хела. Мотивацијата за грешката може да биде влијанието на јазикот на оригиналот, во кој името се наоѓа во падежна форма за генитив и има наставка -и. Неможноста да се одреди општата форма на именката е доста често кај изучувачите на полскиот јазик на почетно ниво, особено кога падежите не им се познати на изучувачите, односно нивниот мајчин јазик е аналитички, како што е во случајов. Па така, често се случува да се смени родот на личностата, пр. Александар да стане Александра, ако именката е во генитив и има наставка која се поклопува со суфиксот за женски род. Очигледно, овде тоа не е слу-

8 Л. Минова-Гуркова, Синтакса на македонскиот стандарден јазик, Скопје 1994, стр. 205. 
чај, бидејќи преведувачот не е на тоа ниво на познавање на јазикот, но неговото невнимание може да доведе до забуна кај читателот, доколку личното име не било споменувано претходно.

Што се однесува до сопствените именки, тие се сметаат за културни елементи, кои на еден особен начин се врзуваат со културата на дадената земја. Карактеристични се исклучително за културата на оригиналот, или пак се попознати во оваа култура и создаваат проблеми при преводот. Во нив влегуваат главно личните имиња и топонимите. Тие најчесто не се преведуваат и се сметаат за непреводливи, бидејќи не ги предизвикуваат истите реакции и асоцијации кај читателите на оригиналот (кои се припадници на таа култура и на кои им се познати тие имиња) и кај читателите на преводот (за кои тие се туѓи имиња кои ништо не им кажуваат). Од друга страна, овде се работи за анализа на текстови од две блиски и сродни култури, па се поставува прашањето дали полските имиња кои имаат еквиваленти во македонската култура треба да се предаваат како во оригиналот или да се адаптираат. Таков е и овој пример:

7а. Штотуку влезе во улицата Долних Млинув, каде што живееше Хела Бертс (стр. 16).

7б. Właśnie wchodził w ulicę Dolnych Młynów, na której mieszkała Hela Bertz (стр. 17).

Тука е предадено името на улицата во падежот во кој стои во оригиналниот текст, иако, како што веќе беше споменато, целниот јазик не познава падежи. Во тој случај ни е потребна номинативната форма, т.е. 'Долне Млини', а ако се одлучиме за адаптација овој израз би звучел 'Долни мелници (евентуално, воденици)'. Освен тоа, на полски улицата е секогаш во зависен падежен однос со името кое го носи, што означува посесивност, па ако сакаме да бидеме доследни на тоа, во преводот тоа би можело да биде предадено со средствата својствени на еден аналитичен јазик кои го изразуваат истото, односно со предлогот на: улиц̧ата на Долните мелници. Вака, како што е предаден во преводот, овој израз не се вклопува во јазичниот систем на македонскиот јазик, а со тоа не е ни во духот на македонскиот јазик.

Следниов е уште еден пример за тоа дека прецизноста, точноста и издржливоста до крајот на едно огромно дело е важна компетенција во книжевниот превод: 
8а. ...и во истиот миг се сети дека голем број од неговите рустифицирани сонародници и родени Руси дојдоа да ѝ помогнат и на неговата земја во овдешната револуција (стр. 365).

8б. ...i w tej chwili przypomniał sobie, że mnóstwo zrusyfikowanych autochtonów, a nawet rdzennych Rosjan przyszło do jego kraju pomagać tutejszej rewolucji (стр. 418).

Овде, немарната печатна грешка доведува до бесмислено ново значење на зборот. Имено, придавската форма рустифициран, изведена од именката рустификација што се употребува, главно, во архитектурата, би означувала 'урбани сонародници, на кои им се додадени традиционални елементи за да им се даде изглед на нешто старо'. Целиот тој контекст на русификацијата во полската култура, спомената во романот, е многу важен за да се разбере поентата кон која стремел авторот, а е изгубена поради небрежноста, мрзеливоста и некреативноста на преведувачот. „Задачата на преведувачот е да ги познава двете култури за да направи меѓукултурен превод", , како и да има општа култура и доволно да го познава предметот на преводот, во тоа вклучувајќк ги и реалиите на земјата на оригиналниот текст.

Имено, овој роман не е единствениот во кој Виткаци на апсурден начин го изразува својот страв од социјалистичката ревулуција и од нападот на Полска од страна на Советите. Потврда на неговото визионерство е советската инвазија на 17 септември 1939 г., по која веднаш се самоубил. Но, поврзаноста на полската со руската култура не започнува оттука, туку таа се провлекува низ целата полска историја, векови наназад и воглавно има негативна конотација по патриотските чувства на Полјаците. Таква е атмосферата во последниот дел од романот, во кој се појавуваат и дијалози на руски говор кој се зборувал на тогашните полски територии и бил мешавина од двата јазика. Во ваков случај, преведувачот треба да биде свесен дека оваа култура не му е многу позната на целниот читател, освен ако тој немал некој посебен интерес за неа. Но целта на преводот треба да биде да му го приближи оригиналот на целниот читател, односно да привлече што поголем број читатели од целната група, што значи, некои работи кои на читателот на оригиналот можат да му бидат познати, треба да бидат подетално објаснети за читателите на преводот, на кои, се разбира, му се сосема непознати. Имаме ваков пример:

\footnotetext{
${ }^{9}$ A. Bednarczyk, Kulturowe aspekty przektadu literackiego, Katowice 2002, стр. 183.
} 
9а. Зошто тука зборуваат со тој проклет руски акцент? (стр. 364).

9б. Skąd ten krajoworosyjski język tutaj? (стр. 418).

Подвлечениот израз не е сосема веродостоен на оригиналот, односно, не ја содржи истата информација. На полски овој израз звучи krajoworosyjski język, што значи 'руски јазик што се зборува во земјава (мислејќи на Полска)'. Наместо читателот да биде заведен дека еден од ликовите зборува полски со руски акцент, односно дека тоа е Русин кој го има научено полскиот јазик и го говори добро, но се забележува странски изговор (а освен тоа тој акцент е негативно обележан од страна на другиот соговорник), преведувачот требало да ги искористи сите средства со кои располага во целниот јазик и да пронајде функционален еквивалент како „полско-руски јазик” или со вклучување на малку креативност да измисли некој неологизам како, на пример, ,доморуски”.

Понатаму, во преводот, како одговор на ова прашање се појавува:

10а. Тој дојде од липтовската страна (стр. 365).

10б. On od luptowskiej strony (стр. 418).

Ваквиот превод е недоволно јасен за еден просечен читател на делото, кој не е воводен во претходно опишаната ситуација. Имено, придавката изведена од именката која го означува топонимот Липтов - регион во северна Словачка, на соседната страна од Татрите, на целниот читател не му дава информација дека се работи за географска одредница, па веројатно би било подобро да се даде поширок опис, како: Тој е дојден од другата страна на Татрите, од Липтов. Тоа би било подолга варијанта, која содржи повеќе информации отколку оригиналот, но ако целта на преводот е туѓата смисла да ја направи разбирлива $^{10}$, тогаш таа може да биде оправдана.

Последниот пример кој ќе го наведеме бара од преведувачот да има способност за разбирање на текстот, односно за декодирање:

11а. Си дошол да нѐ шпионираш за липтовските контрареволуционисти?

Шпионираш? А? (Акцентот на последниот слог)... (стр. 366).

116. Szpionić chodzisz od kontrewolucjonnych luptaków? Co szpiegował? (Akcent na ostatniej zgłosce) (стр. 419).

${ }^{10}$ Cf. P. Bukowski, M. Heydel, Wspótczesne teorie przekładu. Antologia, Kraków 2009, стр. 26. 
Целиов фрагмент нема логика и е бесмислен, поради претходно споменатата придавска определба од регионот Липтов, како и поради употребената именка со неа, која не се вклопува во македонскиот јазичен систем, односно постојат само контрареволуционери, а не контрареволуционисти. Сосема неразбирлива е напомената во заградата. Очигледно е дека оригиналниот текст не е разбран како што треба, или се преведувало од збор до збор, со цел да се доврши задачата на тн. преведување. Ова е еден од примерите на директен говор, каде што се употребува погореспоменатиот „полско-руски” или „доморуски" јазик. Акцентот на последниот слог се однесува на полскиот глагол szpiegować во 2. л. едн. минато време, но без наставката за лице и род, туку само со -л формата, што се поклопува со руската конјугација и уште со таа напомена во заградата се добива израз кој навистина звучи руски. А во нашиот превод информацијата во заградата е сосема нефункционална и не може да се примени на последниот збор од исказот за да наликува на руски изговор. Тука е потребна стилизација на македонскиот со примеси од рускиот јазик, што бара голема креативност од преведувачот. Но, во најмала рака би можело да се смисли нешто како: „Контрареволуционери од Липтов пратили тебја нас шпионират? Шпионират пришол?” (Акцент на последниот слог). Не е потребно големо познавање на рускиот јазик за да се направи ваква стилизација, а ефектот ќе биде сличен како оној во оригиналот.

Со ваков превод се добива желба делото да се чита во оригинал или на некој друг преводен јазик, или воопшто да не се прочита. Кај книжевниот превод преведувачот треба да е свесен дека сноси голема одговорност за тоа што ќе го направи, бидејќи лошиот превод може да го оцрни и авторот на оригиналот. Делата на Виткаци никако не го заслужуваат тоа и затоа е потребно да се размислува за тоа до каде е границата на можностите на еден книжевен преведувач при изборот на делата кои ќе ги преведува. Овој превод дефинитивно се збогувал со магијата на зборот. 